Praxis : Jurnal Sains, Teknologi, Masyarakat dan Jejaring | Vol. 4 | No. 1 | September 2021

\title{
Studi Literatur Digitalisasi Model 5A untuk Pengendalian Obesitas Saat Pandemi COVID-19
}

\author{
Florentina Dewi Pramesuari, Daniel Aryo Wibowo, \\ Ezra Clement Lie, Jessica Christanti* \\ Universitas Katolik Soegijapranata, Semarang \\ *email korespondensi: jessica@unika.ac.id
}

\begin{abstract}
Abstrak
Pandemi COVID-19 telah berdampak pada peraturan-peraturan kesehatan yang dibuat WHO dan Kemenkes RI. Studi terbaru menunjukkan adanya hubungan yang signifikan terhadap isolasi mandiri dan perubahan perilaku seperti penurunan aktivitas fisik dan penurunan pola makan dengan risiko obesitas. Adanya sosial media dan mobile apps sebagai media komunikasi dapat membantu perubahan perilaku gaya hidup dan pola diet tidak sehat. Penelitian ini bertujuan untuk mengumpulkan dan menganalisa artikel yang berhubungan dengan digitalisasi pelayanan kesehatan terutama pengendalian obesitas dan model 5 A. Metode riset yang digunakan adalah literature review. Artikel didapatkan melalui mesin pencari seperti google scholar dan pubmed dengan kata kunci yaitu "obesity", "epidemiology", "COVID-19", "pandemic", "teknologi", "komunikasi", "edukasi", "promotif" "preventif" dan dipilih full text. Berdasarkan hasil penelusuran literatur didapatkan bahwa digitalisasi pelatihan pengendalian obesitas menggunakan sosial media dan machine learning mobile app dapat meningkatkan kemandirian pasien dalam pengendalian obesitas seperti perubahan perubahan perilaku, pola hidup, dan pola diet.
\end{abstract}

Kata Kunci : Obesitas, teknologi, komunikasi, COVID-19, edukasi.

\section{Abstract}

The COVID-19 pandemic has had an impact on health regulations made by WHO and the Indonesian Ministry of Health. Recent studies have shown a significant association with selfisolation and behavioral changes such as decreased physical activity and decreased diet with risk of obesity. The existence of social media and mobile apps as a medium of communication can help change lifestyle behaviors and unhealthy diet patterns. The purpose of study was to collect and analize healthcare digitalization articles especially obesity management and $5 \mathrm{~A}$ model. The study method was literature review. Fulltext Articles was collected from google scholar and pubmed with some keywords such as obesity, epidemiology, COVID-19, pandemic, technology, communication, education, promotion, prevention. The result stated that the digitalization of obesity management with social media and machine learning mobile app could increase patients independence to improve their weight such as behaviour change, lifestyle and dietary pattern.

Keywords: Obesity, technology, communication, COVID-19, education.

\section{PENDAHULUAN}

Pembatasan aktivitas di luar ruangan akibat pandemi Corona Virus Disease-19 (COVID-19) mengubah pola hidup seperti penurunan aktivitas fisik dan peningkatan konsumsi makanan tidak sehat. Pola hidup selama pandemi menyebabkan terjadinya obesitas lebih mudah. (Ashby, 2020). Penderita COVID-19 dengan obesitas 
Praxis : Jurnal Sains, Teknologi, Masyarakat dan Jejaring | Vol. 4 | No. 1 | September 2021

memiliki risiko terjadinya komplikasi lebih tinggi dengan prognosis lebih buruk dibandingkan penderita dengan berat badan normal. (Lighter 2020 ; Zheng, 2020)

Tingkat prevalensi kelebihan berat badan atau obesitas antara 1980 dan 2013 meningkat $27,5 \%$ untuk orang dewasa dan $47,1 \%$ untuk anak-anak, dengan total 2,1 miliar diseluruh dunia ( $\mathrm{Ng} \mathrm{M}, 2014)$. Berdasarkan RISKESDAS 2018, prevalensi overweight pada orang dewasa terus meningkat $8,6 \%$ pada tahun 2007 hingga $13,6 \%$ pada tahun 2018. Prevalensi obesitas dengan BMI > 27 pada orang dewasa juga meningkat dari $10,5 \%$ tahun 2007 hingga 21,8\% tahun 2018. (Kementian Kesehatan RI, 2018) Peningkatan obesitas pada orang dewasa di Indonesia disebabkan oleh berbagai faktor.

Faktor penyebab obesitas terdiri dari berbagai macam, antara lain faktor genetik, pola makan, aktivitas fisik, obat-obatan, dan hormonal (Kabboui 2018). The National Insitute for Health and Care Excellence menyarankan bahwa pengendalian obesitas harus mencakup rencana diet yang sehat, aktivitas fisik dan strategi dalam melakukan perubahan pola hidup sedentary (Lanigan 2013). Oleh karena itu diperlukan digitalisasi pengendalian obesitas saat pandemi di Indonesia.

Penggunaan teknologi komunikasi meningkat di masa pandemi akibat dari pembatasan aktivitas di luar ruangan. Penelitian di Amerika Serikat menunjukkan bahwa individu yang menggunakan aplikasi kesehatan mHealth sebagai untuk tracking aktivitas fisik, pilihan makanan yang sehat, dan penurunan berat badan menunjukan kepercayaan diri dan kesadaran untuk menjaga kesehatan dan membantu dalam pengambilan keputusan kesehatan. (Bhuyan 2016)
Banyak metode dalam pengendalian obesitas salah satunya adalah kerangka $5 \mathrm{~A}$ (Ask, Assess, Advise, Agree, Assist). Kerangka 5A merupakan metode yang diusung oleh Royal Australian College of General Practitioners (Royal Australian College of General Practitioner, 2016). Pelaksanaan 5A untuk pengendalian obesitas menggunakan teknologi komunikasi memudahkan pasien untuk berkonsultasi dan terhubung dengan tenaga kesehatan. Oleh karena itu, model digitalisasi pengendalian obesitas dikembangkan sebagai upaya optimalisasi pengendalian obesitas pada masyarakat selama pandemi COVID-19.

\section{TINJAUAN PUSTAKA}

Obesitas dan overweight merupakan penumpukan lemak melebihi batas normal dan merupakan salah satu faktor risiko yang meningkatkan kejadian penyakit tidak menular seperti diabetes tipe 2, kanker dan penyakit kardiovaskular (WHO, 2017). Body mass index (BMI) merupakan salah satu indeks umum yang digunakan dalam mengklasifikasikan kelebihan berat badan pada orang dewasa (WHO, 2020) Pada penulisan ini, BMI yang diusung oleh Asia-Pasific Guidelines seperti pada tabel 1 .

Tabel 1. Pedoman klasifikasi obesitas menurut WHO dan Asia pasifik

\begin{tabular}{lcc}
\hline & $\begin{array}{c}\text { WHO } \\
(\mathrm{BMI})\end{array}$ & $\begin{array}{c}\text { Asia- } \\
\text { Pacific } \\
(\mathrm{BMI})\end{array}$ \\
\hline Underweight & $<18,5$ & $<18,5$ \\
\hline Normal & $18,5-24,9$ & $18,5-22,9$ \\
\hline Overweight & $25-29.9$ & $23-24,9$ \\
\hline Obese & $>30$ & $>25$ \\
\hline
\end{tabular}


Praxis : Jurnal Sains, Teknologi, Masyarakat dan Jejaring | Vol. 4 | No. 1 | September 2021

Sumber: Jeong Uk Lim, et al. Comparison of World Health Organization and AsiaPacific body mass index classifications in COPD patients. International Journal of Chronic Obstructive Pulmonary Disease. 2017 .

Riset Kesehatan Dasar (RISKESDAS) tahun 2018 ditemukan bahwa dalam kurun waktu lima tahun insiden obesitas meningkat dari $14,8 \%$ menjadi 22,8\%.(KEMENKES RI, 2018) Control Dissease Center (CDC) pada bulan April 2020 melaporkan pasien COVID-19 yang dirawat dirumah sakit memiliki penyakit sekunder komorbid antara lain hipertensi $(49,7 \%)$, obesitas $(48,3 \%)$, penyakit paruparu kronis $(34,6 \%)$, diabetes melitus $(28,3 \%)$ dan penyakit kardiovaskular $(27,8 \%)$. Obesitas menempati komorbid tertinggi ke-2 pada penderita COVID-19 oleh karena itu manajemen pengendalian obesitas diperlukan dalam kondisi pandemi saat ini. (Garg S, 2020)

\section{Faktor risiko}

Faktor risiko obesitas dipengaruhi oleh banyak faktor. Sebagian besar faktor risiko obesitas yaitu faktor genetik, pola makan, aktivitas fisik.

Seorang anak punya $40 \%$ kemungkinan mengalami kegemukan, bila salah satu orangtuanya obesitas. Bila kedua orangtuanya kelebihan berat badan, maka kemungkinan seorang anak mengalami obesitas pun naik hingga $80 \%$. Sehingga factor keturunan orang tua menderita obesitas mempengaruhi kejadian obesitas pada anak. (Kabbaoui, 2018)

\section{Pola makan}

Faktor yang menghambat keberhasilan diet adalah kurangnya pengetahuan akan nutrisi yang sehat, ketersediaan waktu, sosial budaya dan norma sosial, dan cita rasa makanan.
A. Kurangnya pemahaman dan pengetahuan memiliki keterkaitan dengan pemenuhan nutrisi yang diperlukan oleh tubuh karena minimnya edukasi kemampuan pengetahuan nutrisi dasar, antara lain:

1) Pilihan diet sehat

Berdasarkan pedoman dari NSW Department of Health, penulis mengklasifikasikan kelompok makanan menjadi 3 kategori warna yaitu hijau, oranye dan merah, dimana setiap warna mewakili nilai gizi yang ada didalamnya. Kategori berwarna hijau (pilihan terbaik) merupakan makanan yang tergolong dalam kategori ini adalah pilihan terbaik dan mengandung gizi yang sangat dibutuhkan oleh tubuh. Kategori berwarna oranye (pilih dengan hati-hati) merupakan makanan dan minuman dalam kategori ini harus dipilih secara selektif dan dikonsumsi secara beragam. Makanan dalam kategori oranye tidak boleh mendominasi dalam menu yang akan dikonsumsi, dan tidak dianjurkan dalam jumlah yang banyak. Kategori berwarna merah (dibatasi) merupakan makanan dan minuman dalam kategori ini sebaiknya jarang untuk dikonsumsi atau dikonsumsi dalam jumlah kecil.

2) Alasan suatu makanan dapat dikatakan sehat

3) Cara memahami informasi tentang penelitian nutrisi

4) Cara membaca, mengartikan dan memahami label nutrisi yang diterbitkan oleh produsen

5) Pro dan kontra dari konsumsi suplemen makanan,

6) Informasi mengenai model diet dan makanan. (Yu et al, 2018) 
Praxis : Jurnal Sains, Teknologi, Masyarakat dan Jejaring | Vol. 4 | No. 1 | September 2021

B. Ketersediaan waktu merupakan faktor utama alasan seseorang lebih memilih berbelanja makanan dibandingkan memasak sendiri. Mengonsumsi makanan cepat saji juga merupakan faktor penghambat keberhasilan diet yang sehat, makanan cepat saji seringkali menyajikan rasa yang cenderung lebih enak namun memiliki kandungan nutrisi yang lebih sedikit dibandingkan dengan makanan sehat lainnya seperti sayur dan buah-buahan. (Lachat C, 2012)

C. Norma sosial memiliki pengaruh besar dalam mengatur pola makan, dan pengaturan pola makan yang sehat dapat menghasilkan pilihan makanan yang sehat. Analisis terbaru menunjukkan bahwa pilihan makanan cenderung dicontoh di antara anggota keluarga atau lingkungan sosial. (Shepherd R, 2007)

D. Ketertarikan manusia terhadap rasa manis dan makanan yang gurih memang tidak bisa dipungkiri. Hal tersebutlah yang menjadikan rasa pada makanan sangat berpengaruh pada keberhasilan seseorang dalam melakukan diet. (Drewnowski A, 2007)

\section{Aktivitas Fisik}

Perencanaan makan dan aktivitas fisik merupakan aspek penting dalam terapi nonfarmakologis. Namun sangat disayangkan bahwa dimasa pandemi ini gaya hidup sedentary bertambah cukup banyak dikarenakan adanya kebijakan work from home yang membuat kurangnya aktivitas fisik dan lebih banyak waktu yang dihabiskan untuk duduk maupun berbaring. (Leandro, 2014; Xiang M, 2020)

Dalam upaya promotif dan preventif yang akan dikembangkan penulis, maka proses komunikasi yang akan diadopsi oleh penulis adalah Source, Message, Channel, Reciever $\quad$ (SMCR) of
Communication. Proses komunikasi tersebut dilakukan dengan mengolah sumber informasi untuk dijadikan pesan melalui berbagai media sehingga mempengaruhi penerima informasi. (Charles T, 2013)

Selain proses komunikasi, pengembangan model pengendalian obesitas memerlukan sesuatu kerangka kerja. Oleh karena itu, penulis mengimplementasikan kerangka 5A (Ask, Assess, Advise, Agree, dan Assist) pada model penggunaan teknologi komunikasi berupa diskusi antara peserta dengan tenaga kesehatan (Ask), pengukuran rutin fisik, BMI, dan lingkar pinggang peserta untuk dicatat dan dianalisis (Assess), memberi saran dan edukasi kepada pasien mengenai obesitas (Advise), menyetujui pola perubahan hidup realistik yang dapat dicapai peserta untuk mengurangi obesitas (Agree), serta mendorong dan membantu peserta mengidentifikasi hambatan peserta dalam mencapai tujuannya (Assist). Suatu kerangka kerja memerlukan manajemen yang baik agar dapat diimplementasi oleh karena itu penerapan Planning, Organizing, Actuating, Controlling (POAC) diperlukan sehingga kerangka 5A dapat berjalan dengan baik. (Zhao J, 2016; Payne H.E, 2015)

Beberapa penelitian mengatakan bahwa aplikasi kesehatan di smartphone untuk pengendalian obesitas memiliki peranan yang penting dalam mencapai keberhasilan diet yang sehat. dan hasil yang didapat menunjukkan bahwa sebagian besar aplikasi menyertakan fitur self-monitoring, goal-setting, dan instruksi mengenai cara melakukan perilaku kesehatan. (Middelweerd A, 2014; Conroy DE, 2014; Breton ER, 2011)

Pemanfaatan teknologi pada aplikasi smartphone seperti machine learning mobile apps tengah dikembangkan dalam sektor kesehatan. Penelitian oleh Krzhizhanovskaya, menganalisa 
Praxis : Jurnal Sains, Teknologi, Masyarakat dan Jejaring | Vol. 4 | No. 1 | September 2021

pemanfaatan machine learning mobile apps untuk memprediksi probabilitas anak yang akan mengalami obesitas saat dewasa nanti.(Singh, 2020)

Potensi machine learning yang memiliki dampak perubahan status kesehatan membuat para developer menciptakan program machine learning baik dengan bahasa pemrograman dan tanpa bahasa pemrograman sehingga potensi tersebut dapat terakses oleh semua kalangan. Adapun penelitian machine learning dalam penanganan obesitas masih berfokus pada prediksi penurunan/ peningkatan berat badan dan perhitungan kalori. Dalam gagasan tertulis, penulis mengusulkan scanner makanan yang dikelompokan dalam 3 kategori berdasarkan NSW Department of Health guna optimalisasi pemilihan makanan sehat.

\section{METODE PENELITIAN}

Penelitian menggunakan metode literature review. Jurnal yang digunakan dalam literature review didapatkan melalui database penyedia jurnal international seperti google scholar dan pubmed. Penulis menuliskan kata kunci yaitu "obesity", "epidemiology", "COVID-19", "pandemic", "teknologi", "komunikasi", "edukasi", "promotif", "preventif" dan dipilih full text. Hal lain yang relevan yang penulis gunakan dalam mendapatkan jurnal tentang model penggunaan teknologi komunikasi sebagai upaya pengendalian obesitas pada masyarakat selama pandemi COVID-19. Model digitalisasi pengendalian obesitas dianalisa berdasarkan proses adopsi dari berbagai penelitian sebagai upaya pengendalian obesitas pada masyarakat selama pandemi COVID-19.

Kerangka kerja dan demo pemanfaatan model digitalisasi dilampirkan dalam penulisan ini. Demo pemanfaatan model digitalisasi dikembangkan dengan program teachable machine dari google dan android studio sehingga menjadi prototype demo aplikasi.

\section{HASIL PENELITIAN DAN PEMBAHASAN}

Work from home yang dilakukan semasa pandemi Corona Virus Disease-19 (COVID-19) menyebabkan masyarakat memiliki gaya hidup sedentari. Obesitas merupakan faktor kelompok rentan di masa pandemi COVID-19. Penderita COVID-19 dengan obesitas lebih rentan mengalami berbagai komplikasi penyakit kardiovaskular (S.B Heymsfield 2017)

Manajemen harus diterapkan dalam upaya penyelenggaraan kegiatan edukasi karena dengan menerapkan aspek-aspek manajemen seperti planning, organizing, actuating, dan controlling (POAC), kegiatan edukasi dapat berjalan secara terencana, sistematis, berkelanjutan, dan mencapai tujuan yang telah dibuat dalam hal ini peserta dapat mengerti materi edukasi. (Makbuloh 2011)

Kerangka 5A membahas mengenai individu ataupun kelompok yang akan belajar dalam memilih makanan yang baik dan sehat untuk di konsumsi. Sampai saat ini, belum ada literatur yang menganalisa mengenai implementasi 5A secara online, oleh karena itu penulis ingin mengimplementasikan 5A secara online melalui media komunikasi yaitu platform Whatsapp.

Untuk menjalankan kerangka 5A, dibutuhkan sistem manajemen POAC, yang terdiri:

\section{Planning}

Perencanaan kerangka 5 A yang terdiri dari ask, assess, advise, agree, dan assist antara lain: 
Praxis : Jurnal Sains, Teknologi, Masyarakat dan Jejaring | Vol. 4 | No. 1 | September 2021

a. Ask

i. Sebelum memulai program, peserta terlebih dahulu dikelompokkan ke dalam beberapa kloter berdasarkan BMI peserta. Peserta yang memiliki BMI lebih tinggi akan didahulukan. Dalam 1 kelompok terdapat 5-10 peserta. Fungsi dari pengelompokkan kloter ini adalah berfokus pada peserta yang obesitas dapat menurunkan berat badannya.

ii. Persetujuan peserta dilakukan sebelum memulai behaviour change. Tahap ini bertujuan untuk meningkatkan kepatuhan pemilihan makanan kategori hijau/pilihan terbaik .

iii. Pertanyaan dan persetujuan peserta terdapat pada lampiran. Tahap ini penting karena berat badan merupakan hal yang sensitif bagi beberapa orang karena menyangkut perasaan malu, ketakutan, stigma, dan bias berat badan di kalangan tenaga kesehatan dengan adanya persetujuan dari peserta, maka akan tercipta percakapan non-judgmental yang nantinya memudahkan komunikasi antara tenaga kesehatan dan peserta. (Vallis, 2013)

iv. Pertanyaan-pertanyaan ini disebar kepada peserta berupa kuisioner melalui Google form.

\section{b. Assess}

Pengadaan workshop yang memaparkan cara mengukur berat badan (BB), tinggi badan (TB), lingkar pinggang serta cara mengkalibrasikan timbangan berat badan. Diakhir sesi akan diberikan sesi tanya jawab untuk menguji tingkat pemahaman peserta mengenai materi yang sudah dibawakan dan hasil yang diperoleh dapat dikumpukan melalui google form. Penulis memberikan pilihan bagi peserta untuk melakukan check up baik secara online maupun secara tatap muka menggunakan protokol kesehatan yang ada. Penelitian yang dilakukan oleh Butryn, et al, 2012, menyatakan bahwa adanya perubahan rutinitas pengukuran mandiri berat badan dapat membantu individu untuk mempertahankan kesuksesan penurunan berat badan mereka.

\section{c. Advise}

Setelah mendapatkan data assessment peserta, data peserta akan dianalisa berdasarkan Edmonton Obesity Staging System (EOSS). Peserta dengan tingkatan EOSS 0-1 dapat melanjutkan pengendalian berat badan tanpa diperlukannya penatalaksaan lanjut yang memerlukan kehadiran peserta untuk datang ke klinik. Sedangkan pada tingkatan EOSS 2-4 menganjurkan peserta untuk melakukan konsultasi lebih lanjut pada dokter klinik (Offline/Online). Pada tahap ini, akan dilaksanakan edukasi secara daring melalui media Whatsapp dengan tema "Pengetahuan Nutrisi Dasar". Intervensi menggunakan edukasi nutrisional untuk manajemen obesitas di populasi dewasa yang bertujuan untuk menurunkan berat badan dapat memberikan perubahan dalam pola makan, penurunan konsumsi lemak jenuh, makan manis, dan minuman manis. (Hernández, 2020)

Mencapai pola makan yang sehat merupakan tantangan yang besar dan memiliki banyak halangan. Penelitian tentang nutrisi selalu berkembang, hampir tidak mungkin bagi setiap orang untuk mengikuti setiap perkembangan. Dengan demikian, pengetahuan umum tentang kebutuhan nutrisi dasar harus diketahui. (Yu et al, 2018)

\section{d. Agree}

Penulis menentukan indikator keberhasilan program yang konkret, rinci, terfokus dan terdefinisi dengan baik. Indikator ini disampaikan kepada peserta yang tercantum pada forum google form yang diberikan dalam sesi Ask. Indikator 
Praxis : Jurnal Sains, Teknologi, Masyarakat dan Jejaring | Vol. 4 | No. 1 | September 2021

keberhasilan program antara lain penilaian melalui pretest dan posttest. Peserta difasilitasi aplikasi kategori makanan dan dilakukan sosialisasi penggunaan aplikasi kategori makanan agar memudahkan perubahan variasi makanan dengan mendominasikan kategori berwarna hijau/pilihan terbaik. Tenaga kesehatan perlu mempertimbangkan body-image dan self-esteem peserta saat membuat perencanaan program preventif dan treatment. Ditemukan bahwa sesi edukasi kesehatan membantu menutup jarak (gap) antara body-image yang dirasakan peserta dengan manajemen kontrol berat badan masing-masing individu (Valentin, 2020)

\section{e. Assist}

Tim edukator membantu peserta dengan cara mengidentifikasi dan memfasilitasi (misalnya, motivasi, dukungan) dan hambatannya. Adapun follow up yang dilakukan setelah advise, peserta diminta melaporkan foto makanan yang dikonsumsi pada admin untuk mengkonfirmasi jenis kategori makanan yang dimakan setiap harinya hingga hari ketujuh. Meski peserta sudah difasilitasi aplikasi untuk melakukan kategorisasi makanan, namun tetap diperlukan konfirmasi oleh tim edukator agar terjaga validitas informasi. Setelah itu peserta juga akan diberikan pemaparan informasi mengenai kandungan nutrisi dalam makanan yang dikonsumsi dikarenakan hal tersebut sangatlah berpengaruh dalam mengubah sudut pandang peserta yang mengarah pada perubahan pola makan. (Mhurchu, 2018)

\section{Organizing}

Pada model ini membutuhkan Sumber Daya Manusia (SDM) antara lain tenaga ahli kesehatan, seperti dokter dan perawat yang sudah dilatih manajemen obesitas. Hal ini sependapat dengan penelitian sebelumnya bahwa tidak ada jumlah minimal petugas kesehatan dalam melakukan pelayanan pengendalian obesitas. SDM yang terlatih bermanfaat dalam upaya mempertahankan hasil yang sudah dicapai agar dapat terus berjalan secara berkesinambungan. (Montesi, 2016)

\section{Actuating}

Aplikasi Whatsapp adalah aplikasi yang mudah untuk dioperasikan dan tidak perlu mengeluarkan biaya tambahan selain data internet. (Pranajaya \& Hendra Wicaksono, 2017)

Berdasarkan survei yang dilakukan Hootsuite 2019, didapatkan hasil bahwa media sosial yang paling sering digunakan oleh masyarakat Indonesia adalah Youtube sebesar 88\%, Whatsapp 84\%,Facebook $82 \%$. Karena penggunaan Whatsapp di Indonesia menempati peringkat ke-2 terbanyak, maka peneliti memilih Whatsapp sebagai media promotif dan preventif. (Hootsuite, 2019)

Komunikasi efektif merupakan kunci keberhasilan pada layanan jasa informasi, serta menjamin layanan jasa informasi akan tertangani sesuai dengan yang diharapkan. Untuk menciptakan komunikasi yang efektif diperlukan media/sarana komunikasi yang memadai. Oleh karena itu, Whatsapp merupakan aplikasi chat yang bisa menjadi media komunikasi yang efektif dan bermanfaat bagi penggunanya.(Rahartri, 2019)

Demo aplikasi kategorisasi makanan yang akan diberikan kepada peserta ( gambar 2 dan gambar 3 ). 


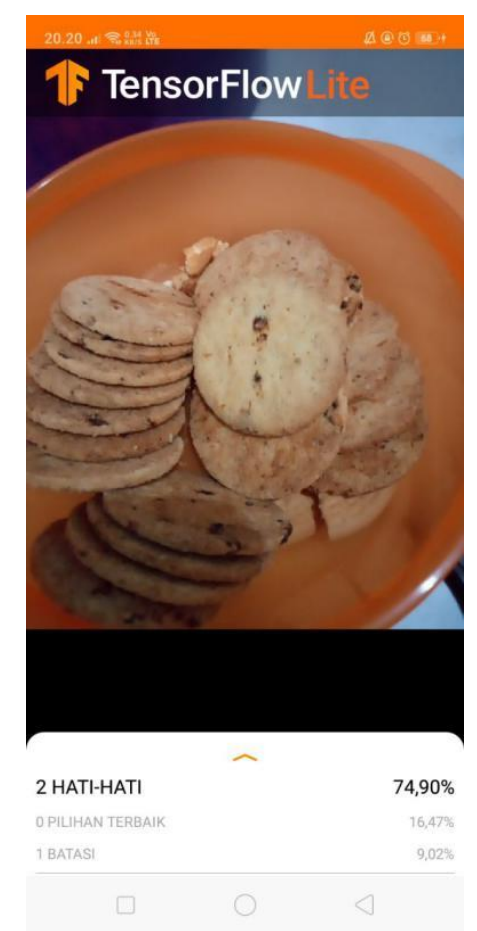

Gambar 2. Hasil Demo Makanan yang Perlu Dipilih dengan Hati-Hati (Oranye/hati hati)

Sumber : Demo aplikasi dari penulis.

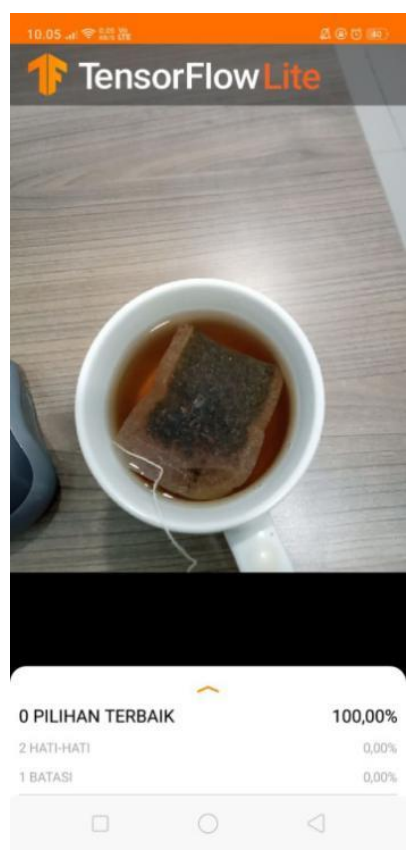

Gambar 3. Hasil Demo Makanan Pilihan Terbaik (Hijau/Pilihan Terbaik)

Sumber : Demo aplikasi dari penulis
Penelitian sebelumnya oleh Kim pada tahun 2020 menunjukan prediksi penurunan berat badan dengan machine learning memiliki tingkat akurasi dari 54\% hingga $81,88 \%$. Penelitian tersebut menunjukan bahwa terdapat manfaat implementasi machine learning sebagai strategi penurunan berat badan pasien berdasarkan prediksi tersebut. (Application, 2020)

\section{Controlling}

Melalui pelatihan ini diharapkan peserta dapat meningkatkan kemandirian mereka dalam pemilihan makanan. Dengan adanya pembinaan makanan yang baik akan memudahkan peserta dalam menerapkannya di kehidupan sehari-hari serta memudahkan pemahaman mengenai keuntungan makanan bagi kesehatan mereka.

Pelatihan yang dilakukan berlandaskan pada klasifikasi pemilihan makanan yang didalamnya mencakup kategori makanan berwarna hijau/pilihan terbaik (pilihan terbaik), oranye/hati-hati (pilih dengan hati-hati), dan merah/batasi (dibatasi). Dalam manajemen makanan yang dikonsumsi, mengurangi ukuran porsi makan kategori oranye/hati-hati dan merah/batasi adalah cara yang efektif untuk dilakukan. Meskipun demikian, pemilihan kategori makanan berwarna hijau/pilihan terbaik dalam jumlah berlebihan juga dapat berkontribusi pada penambahan berat badan. (Valentini K 2017)

\section{SIMPULAN}

Adanya pandemi COVID-19 mengakibatkan terjadinya pembatasan sosial. Pembatasan sosial menyebabkan aktivitas fisik berkurang dan terjadi perubahan pola makan sehari-hari. Akibatnya, prevalensi obesitas meningkat di masyarakat. Dengan memanfaatkan 
Praxis : Jurnal Sains, Teknologi, Masyarakat dan Jejaring | Vol. 4 | No. 1 | September 2021

teknologi komunikasi, program ini menyediakan edukasi nutrisional dan pola makan yang benar untuk masyarakat agar mampu mengendalikan obesitas. Program ini dapat diterapkan sebagai langkah pengendalian obesitas tanpa memerlukan tatap muka secara langsung yang dibatasi selama pandemi.

Keterbatasan penelitian ini yaitu masih berupa rancangan dan perlu penyesuaian untuk merealisasikannya. Penelitian ataupun pelaksanaan lebih lanjut kedepannya diharapkan memiliki masa waktu yang lama dan persiapan yang matang agar program ini dapat berjalan dengan efektif. Selain itu, program ini membutuhkan aplikasi yang dapat mendukung pelaksanaannya. Diperlukan kerja sama antara tenaga dan/atau ahli kesehatan dengan ahli komputer untuk dapat membangun program ini. Terakhir, target populasi dari program ini masih bersifat umum. Untuk penelitian kedepannya dapat dibuat tahap-tahap yang lebih spesifik untuk berbagai kelompok populasi target.

\section{DAFTAR PUSTAKA}

Ashby N. (2020). Impact of the COVID-19 Pandemic on Unhealthy Eating in Populations with Obesity. Obesity (Silver Spring, Md.), 28(10), 18021805. https://doi.org/10.1002/oby.22940

Kim Eunjoo, et al. 2020. Application of Machine Learning to Predict Weight Loss in Overweight, and Obese Patients

Medicine on Korean

Management Program. The Journal of Korean Medicine ; $\quad$ 41(2) 58- 79. Retrieved from https://doi.org/10.13048202 0.41.58

Middelweerd A, Mollee JS, van der Wal CN, Brug J, Te Velde SJInt J Behav
Nutr Phys Act. (2014). Apps to promote physical activity among adults: a review and content analysis, $11 ; 97$.

Conroy DE, Yang CH, Maher JPAm J Prev Med. (2014). Behavior change techniques in top-ranked mobile apps for physical activity. Jun; 46(6):64952.

Bhuyan, Soumitra \& Lu, Ning \& Chandak, Aastha \& Kim, Hyunmin \& Wyant, David \& Bhatt, Jay \& Kedia, Satish \& Chang, Cyril. (2016). Use of Mobile Health Applications for HealthSeeking Behavior Among US Adults. Journal of Medical Systems. 40. 10.1007/s10916-016-0492-7.

Breton ER. (2011). Weight loss-there is an app for that, But does it adhere to evidence-informed practices,Fuemmeler BF, Abroms LC Transl Behav Med. Dec; 1(4):523-9.

Butryn, M.L., Phelan, S., Hill, J.O. and Wing, R.R. (2007), Consistent Self-monitoring of Weight: A Key Component of Successful Weight Loss Maintenance. Obesity, 15: 3091-3096.

Charles T. (2013). Communication model elements for societal behavior representation using agent based models, TSYS School of Computer Science, Colombus State University

Drewnowski A, Bellisle F. (2007). Liquid calories, sugar, and body weight. Am J Clin Nutr ;85: 651-61.

Fabian Sanchis-Gomar, MD, PhD. (2020). Obesity and Outcomes in COVID-19: When an Epidemic and Pandemic Collide.

Kementrian Kesehatan RI. (2018). Factsheet Obesitas, Informasi Obesitas, hal 2.

Garg S, Kim L, Whitaker M, et al. (2020). Hospitalization rates and characteristics of patients hospitalized with laboratory-confirmed coronavirus disease 2019 -COVID-NET, 14

states, March 1-30, 2020. MMWR Morb Mortal Wkly Rep. 
Praxis : Jurnal Sains, Teknologi, Masyarakat dan Jejaring | Vol. 4 | No. 1 | September 2021

;69:458-464.10.15585/mmwr.mm6915 e3.

Hernández, Lourdes López, et all. (2020). Improved Nutritional Knowledge in the Obese Adult Population Modifies Eating Habits and Serum and Anthropometric Markers. Nutrients, 12, 3355; doi:10.3390/nu12113355

Hootsuite and We Are Social. (2020). Digital in 2020 : Essential Insights Into Internet, Social Media, Mobile, and E-Commerce Use Around The World.

Kabbaoui, M.E., et al. (2018). Prevalence of and risk factors for overweight and obesity among adolescents in Morocco. EMHJ Vol. 24 No.6

Kementrian Kesehatan RI. (2018). EPIDEMI OBESITAS.

Kementrian Kesehatan RI. (2018) Hasil Utama Riskesdas. hal 89-90.

Lanigan, J, Collins, S, Birbara, $\mathrm{T}$ et al. (2013). The TrimTots programme for prevention and treatment of obesity in preschool children: evidence from two randomised controlled trials. Lancet 382,58 .

Lachat C, Nago E, Verstraeten R, Roberfroid D, Van Camp J, Kolsteren P. (2012). Eating out of home and its association with dietary intake: a systematic review of the evidence.

$$
\text { Obesity Rev 13:329-46. }
$$

Leandro Fornias Machado de Rezende et al. (2014). Sedentary Behavior and Health Outcomes: An Overview of Systematic Reviews.

Lighter J, Phillips M, Hochman S, et al. (2020). Obesity in patients younger than 60 years is a risk factor for Covid-19 hospital admission. Clin Infect Dis. 71(15):896-897.

Makbuloh, D. (2011). Quality Management of Islamic Education, Model Development of Theory and Application of Quality Assurance Systems, Cet. I;Jakarta: PT. Rajagrafindo Persada.
Mhurchu, C.N., et all. (2018). Do nutrition labels influence healthier food choices? Analysis of label viewing behaviour and subsequent food purchases in a labelling intervention trial. Appetite, Volume 121. Retrieved from https://doi.org/10.1016/j.appet.2017.11 .105 .

Montesi L, El Ghoch M, Brodosi L, Calugi S, Marchesini G, Dalle Grave R. (2016). Long-term weight loss maintenance for obesity: a multidisciplinary

approach. Diabetes Metab Syndr Obes. 9:37-46

$\mathrm{Ng} \mathrm{M}$, Fleming $\mathrm{T}$, Robinson $\mathrm{M}$, et al. (2014). Global, regional, and national prevalence of overweight and obesity in children and adults during 19802013: a systematic analysis for the Global Burden of Disease Study 2013. Lancet. $\quad 384(9945): 766-781 . d o i:$ 10.1016/S0140-6736(14)60460-8.

Payne H.E., Lister C., West J.H., Bernhardt J.M. (2015). Behavioral functionality of mobile apps in health interventions: A systematic review of the literature. JMIR mHealth uHealth. 3 doi: 10.2196/mhealth.3335.

Pranajaya, \& Hendra Wicaksono. (2017). Pemanfaatan Aplikasi WhatsApp (WA) Di Kalangan Pelajar (Studi kasus Di MTs Al Muddatsiriyah dan MTs jakarta Pusat). Prosiding SNaPP2017 Sosial, Ekonomi, Dan Humaniora, Vol 7, No.1, 98-109.

Rahartri. (2019). "Whatsapp" Media Komunikasi Efektif Masa Kini (Studi Kasus Pada Layanan Jasa Informasi Ilmiah Di Kawasan Puspiptek).Visi Pustaka Vol. 21, No. 2,

Royal Australian College of General Practitioners. (2016). Guidelines for preventive activities in general practice. 9th ed. RACGP, Editor. East Melbourne.

S.B. Heymsfield, T.A. Wadden. (2017). Mechanisms, pathophysiology, and management of 
Praxis : Jurnal Sains, Teknologi, Masyarakat dan Jejaring | Vol. 4 | No. 1 | September 2021 1492

obesity N EnglJ Med, 376, p.

Shepherd R. (2007). Social determinants of food choice. Proc Nutr Soc . 58:80712.

Singh, B., \& Tawfik, H. (2020). Machine Learning Approach for the Early Prediction of the Risk of Overweight and Obesity in Young People. Computational Science - ICCS 2020: 20th International Conference, Amsterdam, The Netherlands, June 3-5, Proceedings, Part IV, 12140, 523535. Retrieved from https://doi.org/10.1007/978-3- 03050423-6_39

S. O'dea (2016). Number of smartphone users worldwide from 2014 to 2019.Statistica. Retrieved from http://www.statista.com/statistics/3306 95/number-of smartphone-usersworldwide/. Accessed 8 Mar 2017

Valentin Ayala R, Bernstein J. (2020). Changing Weight Management Selfefficacy Among Obese Puerto Rican Adults: A Quantitative Study using a Health Coaching Intervention. The Internet Journal of Allied Health Sciences and Practice. p 10;18(1), Article 9

Valentini Konstantinidou, MSc, PhD. (2017). Food Coaching: A New Methodology for an Old Problem. Nutritional Genomics Specialist and Accredited Practitioner Coach (IIC\&M), Spain.

Vallis, M., Piccinini-Vallis, H., Sharma, A. M., \& Freedhoff, Y. (2013). Clinical review: modified 5 As: minimal intervention for obesity counseling in primary care.

Canadian family physician Medecin de famille canadien, 59(1), 27-31.)

Xiang M., Zhang Z., Kuwahara K. (2020). Impact of COVID-19 pandemic on children and adolescents' lifestyle behavior larger than expected. Prog. Cardiovasc. Dis. doi: 10.1016/j.pcad.2020.04.013.
Yu et al. (2018). JACC Health Promotion Series. Cardiovascular Disease Prevention by Diet Modification. 917

Zhao J., Freeman B., Li M. (2016). Can mobile phone apps influence people's health behavior change? An evidence review. J. Med. Int. Res.18 doi: 10.2196/jmir.5692.

Zheng K.I., Gao F., Wang X.B. (2020). Obesity as a risk factor for greater severity of COVID-19 in patients with metabolic associated fatty liver disease. Metabolism. 108. 